\title{
CONTRATO DE CORRETAGEM RESPONSABILIDADES QUANTO À SEGURANÇA JURÍDICA DO CONTRATO PRETENDIDO E COMISSÃO PELO RESULTADO ÚTIL. UM ESTUDO À LUZ DO CÓDIGO CIVIL
}

Alexandre Junqueira Gomide*

Sumário: Introdução - 1 . Contrato de corretagem à luz do código civil de $2002-$ 2. Segurança jurídica e contrato de corretagem - 3. Resultado útil e comissão de corretagem - Referências.

\section{INTRODUÇÃO}

O desenvolvimento do mercado imobiliário, sobretudo a partir do início dos anos 2000, atraiu inúmeras pessoas para atuarem como corretores de imóveis, profissional que tem papel fundamental nas transaçōes imobiliárias.

A principal função do corretor imobiliário é aproximar pessoas para que o negócio pretendido por ambos seja concretizado. Em regra, somente com tal concretização é que a comissão do corretor é devida.

Num passado não tão distante, era comum a figura do corretor autônomo que trabalhava em um pequeno escritório ou até mesmo sem um local definido.

* Mestre em Direito Civil pela Faculdade de Direito da Universidade de São Paulo. Especialista e Mestre em Ciências Jurídicas pela Faculdade de Direito da Universidade de Lisboa, em Portugal. Advogado. Professor. Colaborador do Blog Civil \& Imobiliário (www.civileimobiliario. com.br). Fundador do IBRADIM - Instituto Brasileiro de Direito Imobiliário. Membro efetivo do Instituto dos Advogados de São Paulo. 
Atualmente, a maioria dos corretores encontra-se associado a alguma imobiliária, mediante contrato de associação específico, nos termos do art. $6^{\circ}, \$ 2^{\circ}$, da Lei $6.530 / 78^{1}$. Atente-se que o referido diploma legal, que regula a profissão do corretor de imóveis, permite que as atribuições do corretor de imóveis também sejam exercidas por pessoa jurídica inscrita, consoante o art. $3^{\circ}$, parágrafo único ${ }^{2}$.

Nesses termos, na maioria dos casos, o contrato de corretagem acaba sendo firmado com a pessoa jurídica (imobiliária), hipótese em que a comissão de corretagem é repartida entre os diversos profissionais que trabalharam para a concretização do negócio. Muitas empresas também insistem que o contrato de corretagem seja firmado com exclusividade, prometendo ao cliente facilidades tais como publicidade em jornais de grande circulação, exposição do imóvel aos finais de semana, dentre outros benefícios. Em troca, a empresa de corretagem tem garantido o direito à comissão de corretagem caso a intermediação seja realizada por terceiros ${ }^{3}$.

Uma vez que o trabalho é prestado por grandes imobiliárias, o que se verifica, na prática, é que o serviço não se limita apenas à aproximação das partes, mas envolve, também, serviços prestados por advogados, despachantes, consultores, etc. Tais serviços, diga-se, não são prestados em contratos autônomos, mas, sim, como se fizessem parte do serviço de corretagem prestado pela imobiliária.

Essa confusão de serviços jurídicos e de aproximação prestados em favor das partes tem suscitado algumas questôes controversas. A imobiliária que realiza a intermediação do serviço e, portanto, tem interesse que a venda seja concretizada pode prestar o serviço jurídico de aconselhamento para a concretização do negócio? Aliás, poderia a empresa de corretagem também prestar um serviço jurídico?

1 "Art. 60 As pessoas jurídicas inscritas no Conselho Regional de Corretores de Imóveis sujeitam-se aos mesmos deveres e têm os mesmos direitos das pessoas físicas nele inscritas. [...] $\$ 2^{\circ}$ O corretor de imóveis pode associar-se a uma ou mais imobiliárias, mantendo sua autonomia profissional, sem qualquer outro vínculo, inclusive empregatício e previdenciário, mediante contrato de associação específico, registrado no Sindicato dos Corretores de Imóveis ou, onde não houver sindicato instalado, registrado nas delegacias da Federação Nacional de Corretores de Imóveis. (Incluído pela Lei n. 13.097, de 2015)”.

2 "Art. $3^{\circ}$ Compete ao Corretor de Imóveis exercer a intermediação na compra, venda, permuta e locação de imóveis, podendo, ainda, opinar quanto à comercialização imobiliária. Parágrafo único. As atribuiçôes constantes deste artigo poderão ser exercidas, também, por pessoa jurídica inscrita nos termos desta lei."

3 É o que determina o art. 726, do Código Civil: "Art. 726. Iniciado e concluído o negócio diretamente entre as partes, nenhuma remuneração será devida ao corretor; mas se, por escrito, for ajustada a corretagem com exclusividade, terá o corretor direito à remuneração integral, ainda que realizado o negócio sem a sua mediação, salvo se comprovada sua inércia ou ociosidade". 
Sem prejuízo de tal debate, outra discussão é saber quando efetivamente a comissão de corretagem deve ser paga. A comissão de corretagem somente deve ser quitada caso seja efetivamente concretizado o negócio jurídico imobiliário, ou seja, no caso da compra e venda, quando da lavratura da escritura pública? Ou bastaria a assinatura do instrumento de promessa de compra e venda? Seria possível, numa visão ainda mais liberal, que a comissão fosse paga apenas quando da obtenção do consenso das partes aproximadas pelo corretor, antes mesmo da assinatura de qualquer instrumento? Além disso, sendo firmado o instrumento particular de promessa de venda e compra, mas, posteriormente, não tendo o negócio se aperfeiçoado, a comissão continuaria sendo devida? São esses alguns dos questionamentos que pretendemos debater no presente artigo.

É tempo, portanto, à luz do Código Civil de 2002, de tratarmos questôes jurídicas relevantes a respeito desse contrato típico e comumente firmado nas transações imobiliárias.

\section{CONTRATO DE CORRETAGEM À LUZ DO CÓDIGO CIVIL DE 2002}

Embora segundo Carvalho de Mendonçá " "a instituição dos corretores é muito mais antiga que a formação do Direito Comercial", o contrato de corretagem somente foi disciplinado, na legislação civil, quando da edição do Código Civil de 2002. O Código Civil de 1916 não dispunha de tal contrato, sendo a atividade do corretor apenas regulada pelo Código Comercial de 1850 (art. 36 e seguintes).

Pontes de Miranda ${ }^{5}$ afirma que a corretagem é a atividade intermediatriz entre pessoas que desejam contratar, ou praticar para outrem algum ato. Ainda segundo o autor ${ }^{6}$, corretor é aquele que corre de interessado a interessado.

Judith Martins-Costa ${ }^{7}$, em parecer publicado na Revista dos Tribunais, afirma que o contrato de corretagem é formado por dois figurantes, cada qual posicionado

4 CARVALHO DE MENDONÇA, J. X. Tratado de direito comercial. Atualização de Ricardo Negrão. Campinas: Bookseller, t. 1, v. 2, n. 318, p. 348.

5 PONTES DE MIRANDA, Francisco Cavalcanti. Tratado de direito privado: parte especial, Tomo XLIII. Direito das Obrigações: Mandato. Gestão de negócios alheios sem outorga. Mediação. Comissão. Corretagem. 2. ed. Rio de Janeiro: Borsoi, 1958, p. 333.

6 PONTES DE MIRANDA, Francisco Cavalcanti. Tratado de direito privado: parte especial, Tomo XLIII. Direito das Obrigações: Mandato. Gestão de negócios alheios sem outorga. Mediação. Comissão. Corretagem. 2. ed. Rio de Janeiro: Borsoi, 1958, p. 336.

7 MARTINS COSTA, Judith. Parecer publicado na RT vol. 966 e disponível em: http://www. mpsp.mp.br/portal/page/portal/documentacao_e_divulgacao/doc_biblioteca/bibli_servicos_produtos/bibli_boletim/bibli_bol_2006/RTrib_n. 966.13.PDF. Acesso em: 20 jul. 2018. 
em um dos lados: o incumbente e o corretor. Este é a pessoa quem, à conta do incumbente, exercerá a atividade intermediatriz, para encontrar terceiro que conclua negócio jurídico com o incumbente e, com o resultado, adquira direito à comissão. Assim, a intermediação está, pois, no núcleo do conceito.

Claudia Lima Marques e Bruno Miragem, em parecer a respeito de questão controversa envolvendo a comissão de corretagem ${ }^{8}$, noticiam que a doutrina francesa qualifica a corretagem como contrato de realização de uma missão (accomplissement d'une mission), ou seja, o serviço é uma prestação de fazer, que é exatamente o de realizar a missão, que seria exatamente facilitar na conclusão do negócio pretendido pelas partes.

Segundo a própria definição do Código Civil (art. 722), "pelo contrato de corretagem, uma pessoa, não ligada a outra em virtude de mandato, de prestação de serviços ou por qualquer relação de dependência, obriga-se a obter para a segunda um ou mais negócios, conforme as instruções recebidas".

$\mathrm{Na}$ lição de Gustavo Tepedino', trata-se de contrato bilateral, oneroso e normalmente aleatório, uma vez que, segundo o autor, a álea não se mostra essencial à função negocial, nada impedindo uma remuneração comutativamente ajustada. De fato, nada impede que as partes alinhem uma remuneração mensal, por exemplo, para que o corretor trabalhe exclusivamente para tentar viabilizar determinado negócio, sem prejuízo de, ao final, receber a comissão pelo sucesso de seu trabalho.

De todo modo, na prática imobiliária, a regra geral é que o corretor de imóveis envida esforços por sua conta e risco, condicionando sua remuneração à eventual convergência de vontades.

Discute-se, ainda, se o contrato de corretagem seria acessório, ou seja, vinculado ao contrato a que se pretende concluir. Deixaremos esse ponto para tratarmos quando abordarmos temas controversos envolvendo o pagamento da comissão de corretagem.

Analisando-se a natureza jurídica do contrato de corretagem, verifica-se que a atividade do corretor, em regra, seria a do profissional que age com o objetivo de ser firmado o negócio pretendido pelo incumbente. O corretor, portanto, busca pessoas interessadas em firmar o contrato nas condições estabelecidas pelo incumbente.

8 MARQUES, Claudia Lima; MIRAGEM, Bruno. Parecer acostado aos autos 100797860.2014.8.26.0506, do Tribunal de Justiça de São Paulo.

9 TEPEDINO, Gustavo. Questôes controvertidas sobre o contrato de corretagem. In: Temas Atuais de Direito Civil. 4. ed. Rio de Janeiro: Renovar, 2008, p. 139. 
Daí a expressão de Pontes de Miranda ${ }^{10}$ que "o corretor é como quem faz encontrarem-se dois fios elétricos [...] a verdade está que ele fez a ligação".

Pois bem.

Analisando as disposições do Código Civil, a princípio, a aproximação não seria a única prestação devida pelo corretor. Dentre suas atribuições, o corretor também tem a obrigação de prestar todas as informaçōes sobre o andamento do negócio e agir com diligência em seus atos (art. 723, caput). Ocorre que a leitura do parágrafo único do art. 723, do Código Civil, aliada ao fato de que, na prática imobiliária, o serviço de corretagem muitas vezes envolve a prestação de serviços jurídicos, faz-nos refletir se o corretor teria obrigação de observar a segurança jurídica do negócio pretendido pelas partes. É sobre essa questão que se passa a discorrer.

\section{SEGURANÇA JURÍDICA E CONTRATO DE CORRETAGEM}

Embora o contrato de corretagem, como já referido, tenha por escopo aproximar as partes para que seja concretizado o negócio jurídico, a prática demonstra que nem sempre é apenas essa a atuação do corretor ou da empresa de corretagem envolvida na intermediação imobiliária. Ainda que alguns dispositivos do Código Civil qualifiquem a corretagem como forma de mediação ${ }^{11}$, nem sempre o papel do corretor é apenas mediar negócio jurídico a que as partes pretendem firmar.

É justamente por isso que se faz necessário melhor interpretação do quanto disposto no art. 723, parágrafo único, que determina que "sob pena de responder por perdas e danos, o corretor prestará ao cliente todos os esclarecimentos acerca da segurança ou do risco do negócio, das alterações de valores e de outros fatores que possam influir nos resultados da incumbência”.

10 PONTES DE MIRANDA, Francisco Cavalcanti. Tratado de direito privado: parte especial, Tomo XLIII. Direito das Obrigações: Mandato. Gestão de negócios alheios sem outorga. Mediação. Comissão. Corretagem. 2. ed. Rio de Janeiro: Borsoi, 1958, p. 358-359.

11 A esse exemplo, o art. 723 declara que "O corretor é obrigado a executar a mediação com diligência e prudência, e a prestar ao cliente, espontaneamente, todas as informaçôes sobre o andamento do negócio. (Redação dada pela Lei n. 12.236, de 2010).

Segundo Marco Aurélio Bezerra de Melo, há distinções entre a mediação e a corretagem. Enquanto o mediador "é aquele que se coloca de modo equidistante e imparcial perante os contratantes, na qualidade de agente facilitador da contratação que acaso se efetive" o corretor "é personagem que tem lado, contratado que é por quem pretende vender, comprar, alugar, dar em locação, permutar, etc.”. Assim, segundo o autor, "inegavelmente, mediação e corretagem se assemelham, mas a identificação do corretor com um dos personagens da futura contratação é decisiva na caracterização da corretagem propriamente dita". BEZERRA DE MELO, Marco Aurelio. Direito Civil: Contratos. 2. ed. Rio de Janeiro: Forense, 2018, p. 710. 
É relevante asseverar que o art. 723, do Código Civil, no ano de 2010, sofreu alteração legislativa quando da edição da Lei 12.236/2010. Referida lei foi resultado do Projeto de Lei do Senado n. 171/2006, de autoria do Senador Valdir Raupp (PMDB/RO). O resultado da aprovação da Lei 12.236/2010 foi a subdivisão do antigo art. 723, do Código Civil, em caput e parágrafo único ${ }^{12}$.

Segundo se verifica das justificativas do PL, o Senador Valdir Raupp recomendava alteração legislativa para que fosse "estabelecido que o corretor se obriga a, espontaneamente, informar o cliente o grau de risco do negócio, assim como eventuais alterações de valores, condições ou fator capaz de alterar os resultados da incumbência, sob pena de responder por perdas e danos". Ainda segundo as justificativas do projeto, "na prática, a atual redação do art. 723 permite seja o corretor eximido de suas responsabilidades, e anulada a mens legis do comando legal, que é o de assegurar o sucesso da mediação pela efetiva realização do encargo contratado, mediante o justo preço[...]". ${ }^{13}$

O objetivo do PL, como se percebe, foi justamente conferir maior responsabilidade ao corretor de imóveis em razão do seu trabalho de intermediação. Comparativamente à redação original do Código Civil, o atual art. 723 eliminou a expressão destacada a seguir: "prestar ao cliente todos os esclarecimentos que estiverem ao seu alcance, acerca da segurança ou risco do negócio".

Numa interpretação literal, aparentemente a ideia do legislador foi determinar expressamente que o corretor seja responsável não apenas pelas informações sobre a segurança e risco do negócio "a que estiver em seu alcance". Daí o questionamento: seria obrigação do corretor obter documentos e informações suficientes para conferir segurança jurídica ao negócio? Mais do que isso. Após a obtenção de tais documentos, a garantia da segurança jurídica do negócio seria responsabilidade do corretor imobiliário?

A redação do art. 723, do Código Civil, como se vê, pode levar o intérprete a entender que o corretor de imóveis tem a atribuição de prestar serviço jurídico completo de forma a garantir a segurança jurídica da compra.

12 Redação anterior: "Art. 723. O corretor é obrigado a executar a mediação com a diligência e prudência que o negócio requer, prestando ao cliente, espontaneamente, todas as informações sobre o andamento dos negócios; deve, ainda, sob pena de responder por perdas e danos, prestar ao cliente todos os esclarecimentos que estiverem ao seu alcance, acerca da segurança ou risco do negócio, das alterações de valores e do mais que possa influir nos resultados da incumbência”.

13 Disponível em: https://www25.senado.leg.br/web/atividade/materias/-/materia/77939. Acesso em: 28 jul. 2018. 
Por outro lado, poderíamos questionar se não seria papel do corretor apenas a aproximação das partes. $\mathrm{O}$ art. $3^{\circ}$ da Lei 6.530/78 determina que ao corretor compete "exercer a intermediação na compra, venda, permuta e locação de imóveis, podendo, ainda, opinar quanto à comercialização imobiliária”. Essa opinião, nos parece, não implica aconselhamento jurídico, atividade privativa dos advogados, nos termos do art. $1^{\circ}$, inciso II, da Lei 8.906/94.

Como sabemos, a maioria das operações imobiliárias seguem os seguintes passos: (i) tratativas negociais; (ii) auditoria jurídica do imóvel que se pretende adquirir (comumente chamado no mercado imobiliário de due diligence imobiliária); (iii) elaboração e assinatura da promessa de venda e compra; (iv) lavratura da escritura pública e (v) registro da escritura no assento imobiliário competente.

Seria atribuição do corretor de imóveis garantir segurança jurídica em todas essas fases? É ele o responsável pela elaboração da promessa de venda e compra do imóvel? Compete ao corretor de imóveis levantar as inúmeras certidões em nome dos vendedores e referentes ao imóvel para que seja realizada a necessária due diligence imobiliária?

Essa dúvida é ainda maior quando notamos que, de fato, as grandes imobiliárias, por intermédio de seus advogados, efetivamente prestam o serviço jurídico de aconselhamento, elaboração do compromisso de venda e compra e até mesmo revisão da escritura pública. Não se trata, atente-se, de profissionais autônomos, independentes, externos e indicados pelo corretor de imóveis. Na realidade, tais advogados são funcionários da própria imobiliária e recebem seus honorários (ou salário) diretamente da empresa e não do incumbente. É comum o serviço jurídico prestado estar incluído na remuneração do contrato de corretagem.

Ao prestar o serviço de aconselhamento jurídico, resta saber se o advogado (funcionário da imobiliária) possui liberdade e autonomia para aconselhar as partes a não concluírem o negócio, em razão da ausência de segurança jurídica. Essa dúvida é ainda maior quando verificamos que em diversas empresas, o advogado recebe uma gratificação quando o negócio é concluído.

Em alguns casos em que atuamos, percebemos que nem sempre o serviço jurídico prestado pela empresa de assessoria imobiliária foi executado com o zelo que se esperava no tocante à segurança jurídica ${ }^{14}$.

14 É o caso, por exemplo, do quanto se verifica nos autos dos embargos à execução 0000633 40.2018.403.6182, em trâmite perante a 13ª Vara do das Execuções Fiscais da Justiça Federal da Comarca de São Paulo - SP. Nesse caso, o vendedor possuía dívida ativa em seu nome. Embora a empresa que fez a intermediação da venda tenha solicitado a certidão do 
Julgados do Tribunal de Justiça de São Paulo, justamente com fundamento no art. 723, do Código Civil, já condenaram empresas intermediadoras de imóveis pela ausência de segurança na aquisição imobiliária. Nesses termos:

A imobiliária, como especializada, antes da oferta do imóvel a terceiros tem obrigação de analisar a documentação da vendedora, principalmente a matrícula. Nela se vê que duas eram as donas, a autora e outra pessoa considerada como irmã, já falecida e com pais biológicos diversos e constantes da certidão de óbito. Logo, a ré é corresponsável pelo distrato, pois é obrigação básica observar a segurança e risco do negócio, inclusive a certidáo de óbito da coproprietária evidencia que não era irmã da autora, ou seja, não era herdeira direta. $\mathrm{Na}$ realidade, a autora pretendeu vender a parte de Edna, falecida e, sendo irmã de criação, não possuía direitos hereditários. Nesses moldes, cabia ao corretor análise da situação de invalidade do negócio ${ }^{15}$.

Por outro lado, em outro julgado em que o serviço de corretagem também foi prestado por pessoa jurídica, entendeu o Des. Francisco Loureiro que o corretor de imóveis é obrigado "a prestar todos os esclarecimentos que estiverem ao seu alcance acerca da segurança ou risco". Todavia, o julgado não entendeu que é atribuição exclusiva do corretor do imóvel adotar as medidas preventivas e necessárias para conferir segurança jurídica:

[...] Porém, a despeito das obrigaçoes do corretor, não parece razoável que o comprador deixe de adotar as medidas preventivas naturais a um processo de aquisição de imóvel. Em termos diversos, o dever de diligência do corretor não exclui o dever de cautela do comprador, que também deve investigar a situaçáo documental do imóvel e de seu vendedor ${ }^{16}$.

A questão é tormentosa. A princípio, quando o corretor de imóveis é pessoa física e profissional autônomo, a interpretação que deve ser dada ao art. 723, do Código Civil, a nosso ver, é restritiva. Nesse sentido, o corretor não tem obrigação de prestar serviços jurídicos para conferir ampla segurança jurídica às partes.

Isso não significa, evidentemente, que não deve agir de forma minimamente cautelosa. Antes de comercializar qualquer imóvel, compete ao corretor solicitar

distribuidor cível da Justiça Federal (que apontava a inexistência de ações executivas em desfavor do vendedor), não foi solicitada a certidão de dívida ativa, cujo apontamento levou à decretação de fraude à execução.

15 TJSP; Apelação 1011009-74.2015.8.26.0564; Relator (a): Kioitsi Chicuta; Órgão Julgador: 32a Câmara de Direito Privado; Foro de São Bernardo do Campo - $4^{a}$ Vara Cível; Data do Julgamento: 22/06/2017; Data de Registro: 22/06/2017.

16 TJSP; Apelação 0011428-31.2011.8.26.0248; Relator (a): Francisco Loureiro; Órgão Julgador: 6a Câmara de Direito Privado; Foro de Indaiatuba - 1a Vara Cível; Data do Julgamento: 07/11/2013; Data de Registro: 13/11/2013. 
certidão de matrícula atualizada e certidões pessoais em nome dos proprietários. Havendo apontamentos na matrícula, por exemplo, é responsabilidade do corretor de imóveis prestar tal informação a quem pretende comprar ou até mesmo negar-se a comercializar o imóvel.

Por outro lado, não nos parece razoável exigir-se do corretor de imóveis um parecer jurídico conferindo segurança jurídica ao negócio pretendido. Caso, após a concretização do negócio imobiliário, seja declarada ineficácia do ato (por fraude à execução, por exemplo) ou mesmo invalidade por inobservância de requisito legal, é necessário que seja verificado se houve desídia ou má-fé do corretor, nos limites de sua atribuição. Restando comprovado que somente um advogado especialista na área poderia conferir segurança jurídica para o negócio pretendido, não nos parece existir responsabilidade do profissional. Naturalmente, se o corretor deixa de prestar informação relevante, a responsabilidade é por omissão voluntária ${ }^{17}$, nos termos do art. 186, do Código Civil.

A respeito das atribuições do corretor, Pontes de Miranda ${ }^{18}$ afirmou que:

a responsabilidade ordinária do corretor não vai além da função que especificamente lhe incumbe. Em todo negócio jurídico bilateral e plurilateral, há duas ou mais manifestações de vontade que se acordam. O corretor não é figurante. Nenhuma manifestação de vontade parte do correto, nem ele a lança em nome de outrem, como procurador. Ele apenas examina quais as manifestaçôes de vontade que poderiam acordar-se e põe em ligação duas ou mais, que concluam o negócio jurídico. Nem representa, nem faz os interessados manifestarem-se. Os interessados já se manifestaram.

17 Segundo Pontes de Miranda, "a abstenção, omissão, ou ato negativo, também pode ser causa de dano. Se o ato cuja prática teria impedido, ou, pelo menos, teria grande probabilidade de impedir o dano, foi omitido, responde o omitente" (PONTES DE MIRANDA, Francisco Cavalcanti. Tratado de direito privado: parte especial, Tomo XXII. Direito das Obrigações: obrigaçōes e suas espécies. Fontes e espécies de obrigaçōes. Rio de Janeiro: Borsoi, 1958, p. 193 e ss). Antunes Varela, a seu turno, afirma que "a omissão, como pura atitude negativa, não pode gerar física ou materialmente o dano sofrido pelo lesado; mas entende-se que a omissão é causa do dano, sempre que haja o dever jurídico especial de praticar um ato que, seguramente ou muito provavelmente, teria impedido a consumação desse dano. Basta pensar, quanto à responsabilidade contratual, que o comportamento faltoso do devedor se traduz mais das vezes numa omissão - em não realizar ele a prestação (de coisa ou de facto positivo) devida”. (ANTUNES VARELA, João de Matos. Das obrigaçôes em geral. v. I. 10. ed. Coimbra: Almedina, 2000. p. 529). Ainda a respeito da responsabilidade civil por omissão, sugerimos a leitura de: NUNES DE CARVAlHO, Pedro Pitta e Cunha. Omissão e Dever de Agir em Direito Civil: Contributo para uma Teoria Geral da Responsabilidade Civil por Omissão. Coimbra: Almedina, 1999.

18 PONTES DE MIRANDA, Francisco Cavalcanti. Tratado de direito privado: parte especial, Tomo XLIII. Direito das Obrigações: Mandato. Gestão de negócios alheios sem outorga. Mediação. Comissão. Corretagem. 2. ed. Rio de Janeiro: Borsoi, 1958, p. 359. 
Em nossa opinião, não é atribuição do corretor de imóveis elaborar due diligence, minutas dos contratos, revisar escritura pública, dentre outras atividades privativas do advogado contratado pela parte (e não pelas partes). Comprador e vendedor, claro, devem estar representados pelos seus advogados. É dever do corretor, na verdade, possuindo dúvidas quanto à segurança jurídica do negócio, aconselhar as partes a contratarem advogado especializado. Além disso, o corretor, valendo-se de sua experiência, com fundamento na boa-fé objetiva (dever de informação) deve prestar todas as informações a respeito da negociação, sobretudo questionamentos que possam macular o negócio futuramente.

Como bem asseverado por Marco Aurélio Bezerra de Melo ${ }^{19}$, o corretor, no afã de fechar o negócio e receber a sua remuneração, não deve sonegar informações ao incumbente que digam respeito à segurança, riscos do negócio, valores a serem despendidos e outros fatores que possam influir nos resultados da incumbência, sob pena de assim agindo, ser responsabilizado por perdas e danos.

Não se olvide, ainda, que o exercício da profissão de corretor de imóveis é permitido ao possuidor de título de técnico em transações imobiliárias, nos termos do art. $2^{\circ}$, da Lei 6.530/2010. Esse curso é comercializado com duração de 960 horas (13 meses) de forma que o profissional esteja apto a prestar todo o apoio para a intermediação imobiliária ${ }^{20}$. Cabe ao corretor, portanto, adotar as diligências mínimas capazes de conferir segurança jurídica ao negócio que pretende intermediar. Em nossa opinião, a obtenção de certidôes pessoais em nome dos vendedores e de certidão atualizada da matrícula é ação básica e imprescindível que o corretor deve adotar antes de iniciar qualquer intermediação imobiliária.

Há outro ponto que merece destaque. A extensão da responsabilidade, ademais, pode ser ainda maior quando o serviço é prestado por empresa de intermediação imobiliária. Referidas empresas, na prática, como forma de facilitação e concretização do negócio jurídico, sugerem que seus próprios advogados conduzam toda a operação imobiliária até a concretização do negócio jurídico.

Ora, em tais circunstâncias, uma vez que a própria empresa se dispõe a garantir a segurança jurídica do negócio às partes, naturalmente irá responder pela eventual falta de cautela/diligência jurídica ao permitir às partes a concretização de negócio jurídico inseguro. Aliás, para os casos em que empresas de corretagem

19 BEZERRA DE MELO, Marco Aurelio. Direito Civil: Contratos. 2. ed. Rio de Janeiro: Forense, 2018, p. 716.

20 Vide: http://www.ead.senac.br/cursos-tecnicos/tecnico-em-transacoes-imobiliarias/?\#aba3. Acesso em: 31 jul. 2018. 
se dispõem a conferir segurança jurídica às partes, a responsabilidade civil por danos causados a elas será objetiva, nos termos do art. 14, do Código de Defesa do Consumidor.

A esse exemplo, cite-se caso em que a empresa que realizou a intermediação da venda e compra deixou de verificar as obrigaçóes assumidas pelo cedente no contrato originário de compromisso de compra e venda, obrigação imprescindível para conferir segurança jurídica ao negócio pretendido pelas partes:

[...] Falha constatada na prestação de serviços de intermediação. O art. 723 do Código Civil expressamente determina ao corretor a obrigação de executar a mediação com diligência e prudência. Esta obrigação envolve a necessária verificação de todas as obrigaçôes originalmente assumidas pelo cedente no contrato originário de compromisso de compra e venda. Se a corretora não age desta forma, preferindo trabalhar com os dados unilateralmente informados pelo contratante, sem se assegurar da correção destes, é porque assume o risco negocial quanto a eventuais danos sofridos pelos seus clientes, considerando a atuação temerária que apresentou. Justamente por isso o art. 723, parágrafo único, do Código Civil, impõe ao corretor a obrigação de responder pelas referidas perdas e danos. Manutenção das verbas sucumbenciais. Sentença mantida ${ }^{21}$.

A jurisprudência do Superior Tribunal de Justiça também parece alinhada nesse sentido. No REsp 1.364.57422, de relatoria do Min. Luis Felipe Salomão, foi reconhecida a responsabilidade da empresa imobiliária que intermediou negócio jurídico sem ao menos solicitar certidões negativas de débitos fiscais e pessoais dos vendedores, onde havia apontamento em razão de açôes em face dos alienantes perante o Tribunal de Justiça do Rio Grande do Sul.

Após a alienação do bem e em razão da descoberta de dívidas, os compradores desistiram da aquisição e sustaram o cheque da corretagem emitido em favor dos corretores. O acórdão do Tribunal de Justiça do Rio Grande do Sul já havia determinado a responsabilidade da empresa imobiliária em ter solicitado tais certidóes, bem como declarada lícita a desistência motivada dos adquirentes para a extinção contratual $^{23}$.

21 TJSP; Apelação 0010795-69.2011.8.26.0361; Relator (a): Edson Luiz de Queiróz; Órgão Julgador: 5a Câmara de Direito Privado; Foro de Mogi das Cruzes - 2a Vara Cível; Data do Julgamento: 27/02/2013; Data de Registro: 08/03/2013.

22 Superior Tribunal de Justiça, REsp 1.364.574/RS, Rel. Ministro LUIS FELIPE SALOMÃO, QUARTA TURMA, julgado em 24/10/2017, DJe 30/11/2017.

23 Segundo a sentença que deu ensejo ao Recurso Especial: "Com efeito, no Contrato de Promessa de Compra e Venda firmado pelos embargantes nada consta sobre a existência de uma ação de execução contra o proprietário do imóvel, como se constata na cópia de fls. 34 a 37 destes 
Ao julgar referido recurso especial, o Min. Salomão assim entendeu:

[...] é dever do corretor prestar ao cliente todos os esclarecimentos acerca da segurança ou do risco do negócio, das alteraçôes de valores e de outros fatores que possam influir nos resultados da incumbência, sob pena de responder por perdas e danos. [...] É dizer, cabe ao corretor diligentemente se inteirar e prestar informaçōes usuais e notórias acerca do título de domínio exIbido pelo vendedor, da regularidade da cadeia dominial, da existência, ou não, de gravames reais e de açôes que envolvam o vendedor e que, v. g, em tese, poderiam conduzir à ineficácia, nulidade ou anulabilidade do contrato de compra e venda, por caracterização de fraude à execução ou contra credores ${ }^{24}$.

Em outro julgado, cuja relatoria também coube ao Min. Salomão, a empresa que realizou a intermediação imobiliária foi condenada a indenizar os danos sofridos pelos adquirentes em razão de não ter pesquisado a respeito de "ações que pudessem levar a vendedora à insolvência”. Segundo o julgado:

é inequívoco que o corretor de imóveis deve atuar com diligência, prestando às partes do negócio que intermedeia as informações relevantes, de modo a evitar a celebração de contratos nulos ou anuláveis, podendo, nesses casos, constatada a sua negligência quanto às cautelas que razoavelmente são esperadas de sua parte, responder por perdas e danos ${ }^{25}$.

No mesmo sentido, alguns autores também manifestam competir às empresas imobiliárias adotarem as cautelas necessárias para que o negócio jurídico seja concretizado com segurança. Segundo Orlando Gomes ${ }^{26}$, "o corretor é obrigado a se conduzir com toda diligência, de sorte a satisfazer, juridicamente, os futuros

autos. Tampouco consta no Contrato de Prestação de Serviços da Imobiliária (fls. 23/24). A existência da referida ação de execução está confirmada nos documentos de fls. 19 a 22 destes autos e sem dúvidas é razão manifestamente justificável para o desfazimento do negócio, pois ao menos em tese o bem imóvel em questão poderia vir a ser atingido. A própria empresa embargada deixou inequívoco que nenhuma informação sobre a ação de execução foi passada aos então promitentes compradores, pois ela própria alegou na sua defesa que se tivesse sabido dos receios dos compradores, à época, teria providenciado os esclarecimentos pertinentes. Disso resulta a certeza de que os representantes da imobiliária embargada agiram com malícia ao não revelarem aos promitentes compradores que havia a pendência de ação de execução contra o proprietário, o que somou à ausência das certidóes pertinentes à segurança do negócio. Descumpriu a imobiliária embargada, destarte, as obrigações que lhe impóe o artigo 723 do Código Civil [...]"

24 Superior Tribunal de Justiça, REsp 1.364.574/RS, Rel. Ministro Luis Felipe Salomão, QUARTA TURMA, julgado em 24/10/2017, DJe 30/11/2017.

25 Superior Tribunal de Justiça, REsp 1.266.937, Rel. Ministro Luis Felipe Salomão, QUARTA TURMA, julgado em 06/12/2011, DJe 01/02/2012.

26 GOMES, Orlando. Contratos. 26. ed. Rio de Janeiro: Forense, 2008, p. 475. 
contraentes, não devendo propiciar a realização de negócios nulos ou anuláveis" (grifamos).

A respeito do tema, discorre Claudio Luiz Bueno de Godoy ${ }^{27}$ :

[...] o atual Código Civil foi explícito ao atribuir ao corretor o dever, primeiro, de informar seu cliente sobre o andamento dos negócios que esteja a promover ou intermediar. Mas não só. Incumbe ainda ao corretor o dever mesmo de esclarecer, de aconselhar seu cliente sobre a segurança e o risco do negócio, portanto incluindo o dever de informar sobre as condições dos interessados em entabulá-lo [...] que implica, decerto, sua obrigação de informar sobre tudo quanto possa influir na realização do contrato. Tanto assim que, acrescente-se, deve o corretor informar sobre alteração de preços dos objetos dos negócios a serem firmados, informando até sobre o que seja relevante a evitar, por exemplo, negócios inválidos. Tudo sobre pena de responder por perdas e danos.

É de se ressaltar, contudo, que tal entendimento não é uníssono na jurisprudência. Em julgado proferido pelo Tribunal de Justiça de São Paulo, não obstante a imobiliária ter deixado de solicitar as certidões em nome dos vendedores, entendeu-se que "o corretor não é garante do negócio jurídico” e que:

a responsabilidade, in casu, deve ser atribuída integralmente aos compradores, porquanto deveriam ter exigido além da certidão vintenária atualizada do imóvel que consta dos autos, àquelas referentes as ações no Foro competente contra os vendedores, possibilitando a verificação se o vendedor era ou não legítimo proprietário do bem $^{28}$.

A despeito de tal julgado, a maioria dos acórdãos de nossa investigação apontam a responsabilidade dos corretores de imóveis e das empresas que realizam a intermediação imobiliária quando deixam de obter documentos relevantes antes de o negócio jurídico ser concluído, causando danos futuros aos adquirentes ${ }^{29}$. Esse

27 GODOY, Claudio Luiz Bueno de. Coord. PELUSO, Cezar. Código Civil comentado: doutrina e jurisprudência. Ed. Manole, 2007, p. 585.

28 Tribunal de Justiça de São Paulo, Apelação 9178940-53.2008.8.26.0000, Rel. Hugo Crepaldi, j. 26/09/2012. v. u.

29 A esse exemplo, cite-se os seguintes julgados do TJSP; Apelação 0003766-35.2012.8.26.0004; Relator (a): Kenarik Boujikian; Órgão Julgador: 34a Câmara de Direito Privado; Foro Regional IV - Lapa - 4a Vara Cível; Data do Julgamento: 15/02/2017; Data de Registro: 21/02/2017); TJSP; Apelação 1012870-62.2014.8.26.0554; Relator (a): Kenarik Boujikian; Órgão Julgador: 12a Câmara Extraordinária de Direito Privado; Foro de Santo André - 2a Vara Cível; Data do Julgamento: 29/01/2016; Data de Registro: 30/01/2016; TJSP; Apelação 0033383-35.2011.8.26.0114; Relator (a): Mendes Gomes; Órgão Julgador: 35a Câmara de Direito Privado; Foro de Campinas - 3a . Vara Cível; Data do Julgamento: 12/08/2013; Data de Registro: 13/08/2013; TJSP; Apelação 0000973-04.2011.8.26.0443; Relator (a): Mary 
posicionamento nos parece o mais acertado, ressaltando, contudo, que a interpretação a ser dada ao art. 723, parágrafo único, deve restringir-se às ações que estão ao alcance dos corretores de imóveis. Não é deste profissional, portanto, a obrigação de conferir segurança jurídica que extrapole os limites do técnico em transações imobiliárias.

\section{RESULTADO ÚTIL E COMISSÃO DE CORRETAGEM}

A última controvérsia que pretendemos abordar no presente artigo diz respeito ao pagamento da comissão de corretagem quando o negócio jurídico não é concretizado pelas partes.

A questão é intimamente ligada à discussão de saber se referido contrato é acessório, ou seja, se sua eficácia estaria vinculada ao contrato que se pretende concluir. Sendo referido contrato entendido como acessório, poderíamos qualificar a obrigação do corretor como obrigação de resultado. Nesses termos, Maria Helena Diniz $^{30}$, ao defender a acessoriedade do contrato de corretagem, afirma que o corretor terá direito a uma "compensação condicional, que dependerá da execução da obrigação de resultado”. Ainda segundo a autora:

[...] na mediação o serviço é prometido como meio para a consecução de certa utilizade; o proprietário do bem a ser vendido, ao contratar o corretor, não objetiva o serviço por ele prestado, mas o resultado útil, que é a obtenção da vontade do contratante para a conclusão do negócio. Logo, apenas quando se verifica tal utilidade é que o corretor terá direito à remuneração. $\mathrm{O}$ serviço do mediador somente traduzirá valor econômico quando resultar no acordo para a efetivação do contrato, que constitui a finalidade de seu trabalho. [...] A mediação consumar-se-á precisamente no momento em que aparecer o acordo de vontade entre os contratantes, mercê da aproximação levada a efeito pelo mediador, quando então estará terminada a sua função.

Esse entendimento também é partilhado por Sílvio de Salvo Venosa ${ }^{31}$, para quem "o objeto da mediação não é uma conduta propriamente dita, mas o resultado

Grün; Órgão Julgador: $7^{a}$ Câmara de Direito Privado; Foro de Piedade - 1a. Vara Judicial; Data do Julgamento: 22/04/2015; Data de Registro: 22/04/2015; TJSP; Apelação 100763455.2014.8.26.0320; Relator (a): Rodolfo Pellizari; Órgão Julgador: 6a Câmara de Direito Privado; Foro de Limeira - 2a Vara Cível; Data do Julgamento: 01/02/2018; Data de Registro: $01 / 02 / 2018$.

30 DINIZ, Maria Helena. Curso de Direito Civil Brasileiro: Teoria das Obrigaçôes Contratuais e Extracontratuais. v. III. 18. ed. São Paulo: Saraiva, 2003, p. 394.

31 VENOSA, Sílvio de Salvo. Direito Civil: Contratos em espécie. v. III. 6. ed. São Paulo: Atlas, 2006, p. 325. 
de um serviço. Na corretagem, existe uma obrigação de resultado. Sem este não há direito à remuneração".

Ocorre que outros autores, sobretudo a partir de artigo defendido pelo Prof. Gustavo Tepedino ${ }^{32}$, passaram a entender que o contrato de corretagem não depende da efetiva concretização do negócio jurídico imobiliário sendo, portanto, obrigação de meio e não resultado. Segundo Tepedino ${ }^{33}$ :

o objeto do contrato de corretagem não consiste em obter o consenso indispensável à celebração do negócio desejado, mas a envidar os seus melhores esforços nessa direção, o que, por sua vez, não se reduz à mera gestão que lhe é cometida no sentido de buscar possíveis compradores [...] a escolha das partes pela modalidade aleatória de remuneração não transforma a obrigação do corretor em obrigação de resultado, pois este último não promete a realização do negócio, nem pode ser responsabilizado por inadimplemento contratual toda vez que não alcance este objetivo. [...] Como já dito, o corretor desenvolve atividade de intermediação, de aproximação útil, cuja função jurídica se revela incompatível com a promessa de obter o consentimento das partes na celebração do negócio.

Pontes de Miranda ${ }^{34}$, da mesma forma, defendia a ausência de acessoriedade do contrato de corretagem:

O contrato de mediação pode existir, valer e ser eficaz, sem que se conclua o contrato para cuja conclusão há a ajuda, como ocorre naqueles casos em que o mediador tem direito à remuneração ou em que há resolução do seu sem que repercuta no outro. [...] Afirmar que o contrato de mediação é acessório é fugir-se à noção mesma da acessoriedade dos contratos.

Araken de $\mathrm{Assis}^{35}$, da mesma forma, ressalta que:

o contrato de corretagem pode existir, valer e se mostrar eficaz, inclusive quanto à remuneração, independentemente do desfazimento do contrato obtido pela atividade intermediadora, conforme resulta da parte final do art. 725. Ora, o autêntico contrato 'acessório', ou dependente, acompanha a sorte do 'principal'. Por isso, a afirmativa de que o contrato é acessório contradiz a 'noção mesma de acessoriedade dos contratos ${ }^{36}$.

32 TEPEDINO, Gustavo. Questōes controvertidas sobre o contrato de corretagem. In: Temas Atuais de Direito Civil. 4. ed. Rio de Janeiro: Renovar, 2008.

33 TEPEDINO, Gustavo. Questôes controvertidas sobre o contrato de corretagem. In: Temas Atuais de Direito Civil. 4. ed. Rio de Janeiro: Renovar, 2008, p. 151/152.

34 PONTES DE MIRANDA, Francisco Cavalcanti. Tratado de direito privado: parte especial, Tomo XLIII. Direito das Obrigações: Mandato. Gestão de negócios alheios sem outorga. Mediação. Comissão. Corretagem. 2. ed. Rio de Janeiro: Borsoi, 1958, p. 239.

35 ASSIS, ARAKEN. Contratos nominados. São Paulo: RT, 2005, p. 248-249.

36 No mesmo sentido: COLTRO, Antônio Carlos Mathias. Contrato de Corretagem Imobiliária. 4. ed. São Paulo: Atlas, 2013, p. 33. 
O Código Civil, por sua vez, não resolve a questão. Segundo o art. 725, “a remuneração é devida ao corretor uma vez que tenha conseguido o resultado previsto no contrato de mediação, ou ainda que este não se efetive em virtude de arrependimento das partes".

O que seria o resultado previsto no contrato? Bastaria a aproximação das partes com consentimento em relação aos valores comerciais envolvidos no negócio pretendido? Ou o resultado útil seria conferido quando, além da conclusão das condições comerciais, as partes também tenham assinado compromisso de venda e compra? Ou o resultado útil somente se daria com a lavratura da escritura de compra e venda?

Nos termos do REsp 1.183.324³7, de relatoria da Ministra Nancy Andrighi, entendeu-se:

[...] Pelo novo regime, deve-se refletir sobre o que pode ser considerado resultado útil, a partir do trabalho de mediação do corretor. A mera aproximação das partes, para que se inicie o processo de negociação no sentido da compra de determinado bem, não justifica o pagamento de comissão. A desistência, portanto, antes de concretizado o negócio, permanece possível. 4. Num contrato de compra e venda de imóveis é natural que, após o pagamento de pequeno sinal, as partes requisitem certidões umas das outras a fim de verificar a conveniência de efetivamente levarem a efeito o negócio jurídico, tendo em vista os riscos de inadimplemento, de inadequação do imóvel ou mesmo de evicção. Essas providências se encontram no campo das tratativas, e a não realização do negócio por força do conteúdo de uma dessas certidões implica mera desistência, não arrependimento, sendo, assim, inexigível a comissão por corretagem. 5. Recurso especial não provido.

No julgado acima, portanto, entendeu-se que mesmo que as partes já tenham concluído a negociação em termos comerciais, inclusive com o pagamento de sinal, a comissão de corretagem não é devida porque o negócio jurídico pretendido pelas partes não foi concluído. É relevante destacar que no referido julgado o negócio pretendido somente não foi concluído uma vez que uma das partes realizou due diligence imobiliária onde foram apontados elementos concretos de que a compra não era segura juridicamente. Segundo o acórdão:

Numa compra e venda é praxe que as partes, aproximadas pelo corretor, informem-se sobre a idoneidade do vendedor, características do imóvel, existência de ações cíveis que possam gerar risco de eviç̧ão, capacidade econômica do comprador e assim por diante. Aproximar meros interessados não implica obter um resultado útil para

37 REsp 1.183.324/SP, Rel. Ministra Nancy Andrighi, terceira turma, julgado em 18/10/2011, DJe 10/11/2011. 
a atividade de corretagem. Todas essas pesquisas, posteriores à aproximação inicial, são parte da negociação que precede o acordo de vontades. ${ }^{38}$

Em outro caso, também de relatoria da Min. Nancy Andrighi, entendeu-se que "a assinatura da promessa de compra e venda e o pagamento do sinal demonstram que o resultado útil foi alcançado e, por conseguinte, apesar de ter o comprador desistido do negócio posteriormente, é devida a comissão por corretagem" ${ }^{\prime \prime}$.

Embora diversos julgados do STJ entendam que a obrigação do contrato de corretagem seja de resultado, a maioria dos julgados consultados entende que o resultado útil seria alcançado quando as partes assinam o compromisso de venda e compra, ainda que a escritura não seja lavrada por culpa das partes ${ }^{40}$. É por isso que já se entendeu devida a comissão de corretagem quando, após a assinatura da promessa de compra e venda, a lavratura da escritura não tenha ocorrido por culpa do adquirente, que não obteve o prometido financiamento imobiliário ${ }^{41}$. Decidiu-se:

quando as partes firmam, de algum modo, atos, com mediação da corretora, que geram obrigatoriedade legal de proceder-se ao registro imobiliário, tal como ocorre no caso de celebração de promessa de compra e venda ou de pagamento de sinal, torna-se devida a percepção de comissão de corretagem, mormente quando eventual desfazimento do negócio não decorrer de ato praticado pela corretora ${ }^{42}$.

38 Em outro julgado, também de relatoria da Min. Nancy Andrighi, entendeu-se: "A assinatura da promessa de compra e venda e o pagamento do sinal demonstram que o resultado útil foi alcançado e, por conseguinte, apesar de ter o comprador desistido do negócio posteriormente, é devida a comissão por corretagem. 6. Recurso especial não provido". (REsp 1.339.642/RJ, Rel. Ministra Nancy Andrighi, terceira turma, julgado em 12/03/2013, DJe 18/03/2013)

39 REsp 1.339.642/RJ, Rel. Ministra NANCY ANDRIGHI, TERCEIRA TURMA, julgado em 12/03/2013, DJe 18/03/2013.

40 No mesmo sentido, verificar: "CIVIL E PROCESSUAL CIVIL. CORRETAGEM. COMISSÃO. NEGÓCIO NĀO REALIZADO. MERA APROXIMAÇÃO DAS PARTES. O contrato de corretagem não impõe simples obrigação de meio, mas sim uma obrigação de resultado. Recurso não conhecido.” (REsp 208.508/SC, Rel. Min. CESAR ASFOR ROCHA, QUARTA TURMA, DJ de 11/11/2002).

41 Também entendendo devida a comissão de corretagem quando o negócio não se conclui em razão de o adquirente não ter obtido o prometido financiamento, vide: TJSP, Apelação 1012416-03.2014.8.26.0451, Rel. Mary Grun, j. 10/12/2015 e TJSP; Apelação 007346461.2012.8.26.0576; Relator (a): James Siano; Órgão Julgador: 5a Câmara de Direito Privado; Foro de São José do Rio Preto - 7a Vara Cível; Data do Julgamento: 11/12/2013; Data de Registro: 23/12/2013.

42 REsp 1.228.180/RS, Rel. Ministro RAUL ARAÚJO, QUARTA TURMA, julgado em 17/03/2011, DJe 28/03/2011. 
Outros inúmeros acórdãos também entendem que o mero arrependimento de uma das partes em concluir o negócio jurídico, após assinado o instrumento particular de venda e compra, não implica em devolução da comissão de corretagem (nos exatos termos da parte final do art. 725, do Código Civil):

AÇÃO DE COBRANÇA - COMISSÃO DE CORRETAGEM - FINALIZAÇÃO DO NEGÓCIO - ARREPENDIMENTO POSTERIOR - RESULTADO ÚTIL - APROXIMAÇÃO DAS PARTES - Corretora de imóveis que deve ser remunerada pelo serviço prestado quando além de aproximar as partes, formalizou-se instrumento particular de promessa de compra e venda - depois de ter pago parte do sinal e da comissão de corretagem, os réus desistiram do contrato; - Trabalho da corretora que foi realizado, havendo resultado útil - inteligência do art. 725 do CC. RECURSO PROVIDO $^{43}$.

Em nossa opinião, concordando com Gustavo Tepedino e outros autores aqui citados, também consideramos o êxito do contrato de corretagem independente da conclusão do negócio pretendido pelas partes. Para nós, compete ao corretor de imóveis, previamente à aproximação das partes, realizar o estudo prévio das condições do negócio pretendido pelo incumbente.

Tendo realizado um estudo básico da documentação do imóvel e constatando a possibilidade de comercialização, o passo seguinte será buscar pessoas interessadas para a concretização do negócio. Após localizar pessoa que consente com as condições comerciais e tendo aproximado as partes, nesse momento, o resultado útil foi alcançado.

43 TJSP; Apelação 1003166-33.2015.8.26.0152; Relator (a): Maria Lúcia Pizzotti; Órgão Julgador: $37^{\text {a }}$ Câmara Extraordinária de Direito Privado; Foro de Cotia - 3a Vara Civel; Data do Julgamento: 29/11/2017; Data de Registro: 29/11/2017. No mesmo sentido: "CIVIL. MEDIAÇÃO. APROXIMAÇÃO EFETIVA DAS PARTES. COMISSÃO DE CORRETAGEM DEVIDA. RESULTADO ÚTIL COMPROVADO. SENTENÇA MANTIDA. 1. A partir dos precedentes recentes do e. STJ, sendo a compra e venda um ato complexo, 'somente com a análise, no caso concreto, de cada uma dessas fases, é possível aferir se a atuação do corretor foi capaz de produzir um 'resultado útil', para fins de percepção da remuneração de que trata o art. 725 do CC/02', sendo certo, contudo, que 'a assinatura da promessa de compra e venda e o pagamento do sinal demonstram que foi alcançado um resultado útil e, por conseguinte, é devida a comissão de corretagem'. 2. No caso concreto, a aproximação inicial das partes é incontroversa, a extensa negociação intermediada pela autora está demonstrada por documentos, e o negócio efetivamente se concretizou, fato que os próprios requeridos também admitem. Logo, não se podendo negar a existência de resultado útil decorrente da efetiva aproximação das partes, é caso de se manter a r. sentença de procedência. 3. Recurso improvido. (TJSP; Apelação 1017445-79.2015.8.26.0554; Relator (a): Artur Marques; Órgão Julgador: 35a Câmara de Direito Privado; Foro de Santo André - 1a Vara Cível; Data do Julgamento: 23/10/2017; Data de Registro: 24/10/2017) 
Assim, para nós, sequer haveria a necessidade de assinatura da promessa de compra e venda caso, por exemplo, o incumbente, por capricho ou arrependimento, desistisse de assinar o contrato. Caso as condiçōes do incumbente sejam aceitas e tendo o corretor apresentado pessoa disposta a contratar, a nosso ver, a comissão de corretagem é devida, nos exatos termos do art. 725, do Código Civil.

Mais do que isso. Pensamos que, se o contrato determinar que a comissão de corretagem é devida com a mera aproximação de pessoas que aceitem as condições comerciais pretendidas pelo incumbente, o pagamento da corretagem se faz devido. Caso as partes não firmem o contrato por questôes alheias à vontade do corretor, a comissão de corretagem pode ser cobrada em ação contra a pessoa que, embora tenha prometido contratar e se obrigado a tanto, deixou de firmar o instrumento necessário para concluir o negócio jurídico.

É evidente que se uma das partes demonstrar que apenas não concluiu o negócio em razão da falta de segurança jurídica, não se trata de arrependimento pura e simplesmente, mas desistência justificada, oportunidade em que a comissão não é devida porque ausente suporte fático que garantia a segurança do negócio intermediado pelo corretor.

Em nossa opinião, portanto, o pagamento da comissão de corretagem pode ser devido quando há o "consenso quanto aos elementos essenciais do negócio"44. Embora alguns julgados também possuam o mesmo entendimento, as decisóes continuam atrelando o resultado útil à assinatura do compromisso de compra e venda. Nesse sentido:

Embargos à execução de título extrajudicial. Cheque emitido para pagamento de comissão de corretagem. Obtenção de resultado útil. Exigibilidade do débito. A aproximação das partes pelo corretor foi frutífera, e o resultado útil foi por ele obtido.

44 REsp 1.183.324/SP, Rel. Ministra NANCY ANDRIGHI, TERCEIRA TURMA, julgado em 18/10/2011, DJe 10/11/2011. No mesmo sentido: Embargos à execução de título extrajudicial. Cheque emitido para pagamento de comissão de corretagem. Obtenção de resultado útil. Exigibilidade do débito. A aproximação das partes pelo corretor foi frutífera, e o resultado útil foi por ele obtido. Ainda que o negócio venha a ser desfeito - o que, até o presente momento, não ocorreu - não seria possível retirar ao embargado o direito ao recebimento pelo trabalho desempenhado. "Resultado útil" deve ser entendido como a aproximação das partes pelo corretor, até o ponto de obter consenso quanto aos elementos essenciais do negócio. E, na hipótese dos autos, a atuação do corretor resultou, efetivamente, na definição quanto à realização do negócio, fazendo incidir a norma do art. 725, parte final, do Código Civil. Apelação provida. (TJSP; Apelação 1002416-62.2015.8.26.0077; Relator (a): Sandra Galhardo Esteves; Órgão Julgador: $12^{\text {a }}$ Câmara de Direito Privado; Foro de Birigui - 1a Vara Cível; Data do Julgamento: 27/09/2017; Data de Registro: 27/09/2017). 
•• Direito Civil: Estudos | Coletânea do XV Encontro dos Grupos de Pesquisa - IBDCivil

Ainda que o negócio venha a ser desfeito - o que, até o presente momento, não ocorreu - não seria possível retirar ao embargado o direito ao recebimento pelo trabalho desempenhado. 'Resultado útil' deve ser entendido como a aproximação das partes pelo corretor, até o ponto de obter consenso quanto aos elementos essenciais do negócio. E, na hipótese dos autos, a atuação do corretor resultou, efetivamente, na definição quanto à realização do negócio, fazendo incidir a norma do art. 725, parte final, do Código Civil. Apelação provida ${ }^{45}$.

Ao final, ousando discordar da jurisprudência majoritária, entendemos que a comissão de corretagem pode, sim, ser devida, caso comprovada a diligente intermediação do corretor de imóveis, que resulta na efetiva aproximação das partes. Nessa oportunidade, ainda que o compromisso de venda e compra não tenha sido assinado pelas partes, mas em razão de motivos alheios à vontade do corretor, a comissão poderá ser devida.

\section{REFERÊNCIAS}

ANTUNES VARELA, João de Matos. Das obrigações em geral. v. I. 10. ed. Coimbra: Almedina, 2000.

ASSIS, ARAKEN. Contratos nominados. São Paulo: RT, 2005.

BEZERRA DE MELO, Marco Aurelio. Direito Civil: Contratos. 2. ed. Rio de Janeiro: Forense, 2018.

CARVALHO DE MENDONÇA, J. X. Tratado de direito comercial. Atualização de Ricardo Negrão. Campinas: Bookseller, t. 1, v. 2.

COLTRO, Antônio Carlos Mathias. Contrato de Corretagem Imobiliária. 4. ed. São Paulo: Atlas, 2013.

DINIZ, Maria Helena. Curso de Direito Civil Brasileiro: Teoria das Obrigaçôes Contratuais e Extracontratuais. v. III. 18. ed. São Paulo: Saraiva, 2003.

GODOY, Claudio Luiz Bueno de. Coord. PELUSO, Cezar. Código Civil comentado: doutrina e jurisprudência. Barueri: Manole. 2007.

GOMES, Orlando. Contratos. 26. ed. Rio de Janeiro: Forense, 2008.

MARQUES, Claudia Lima; MIRAGEM, Bruno. Parecer acostado aos autos n. 100797860.2014.8.26.0506, do Tribunal de Justiça de São Paulo.

MARTINS COSTA, Judith. Parecer publicado na RT vol. 966 e disponível em: http:// www.mpsp.mp.br/portal/page/portal/documentacao_e_divulgacao/doc_biblioteca/bi-

45 TJSP; Apelação 1002416-62.2015.8.26.0077; Relator (a): Sandra Galhardo Esteves; Órgão Julgador: $12^{\text {a }}$ Câmara de Direito Privado; Foro de Birigui - 1a Vara Cível; Data do Julgamento: 27/09/2017; Data de Registro: 27/09/2017. 
bli_servicos_produtos/bibli_boletim/bibli_bol_2006/RTrib_n. 966.13.PDF. Acesso dia 20/07/2018.

NUNES DE CARVALHO, Pedro Pitta e Cunha. Omissão e Dever de Agir em Direito Civil: Contributo para uma Teoria Geral da Responsabilidade Civil por Omissão. Coimbra: Almedina, 1999.

PONTES DE MIRANDA, Francisco Cavalcanti. Tratado de direito privado: parte especial, Tomo XLIII. Direito das Obrigaçōes: Mandato. Gestão de negócios alheios sem outorga. Mediação. Comissão. Corretagem. 2. ed. Rio de Janeiro: Borsoi, 1958.

PONTES DE MIRANDA, Francisco Cavalcanti. Tratado de direito privado: parte especial, Tomo XXII. Direito das Obrigações: obrigações e suas espécies. Fontes e espécies de obrigações. Rio de Janeiro: Borsoi, 1958.

TEPEDINO, Gustavo. Questôes controvertidas sobre o contrato de corretagem. In: TEPEDINO, Gustavo. Temas Atuais de Direito Civil. 4. ed. Rio de Janeiro: Renovar, 2008.

VENOSA, Sílvio de Salvo. Direito Civil: Contratos em espécie. v. III. 6. ed. São Paulo: Atlas, 2006. 
